\title{
The Internet Service Search in the Archives: New Possibilities for Using Archival Materials
}

\author{
Magdalena MAROSZ, PH.D. \\ National Archive in Cracow \\ e-mail: mmarosz@ank.gov.pl
}

The Internet Service Search in the Archives: New Possibilities for Using Archival Materials

\section{ABSTRACT}

The service Search in the Archives is a project of the National Digital Archive. The primary objective of the service is to make available online description of archival materials from the state archives and other cultural institutions. In addition, selected descriptions of archival materials are presented simultaneously with the scans. The principle of service is full accessibility and openness, its use is free and does not require logging in. Copies of archival materials presented in the service, unless indicated otherwise in the descriptions of these materials or on digital copies themselves, can be used freely. For information purposes, it is recommended to indicate the source of a digital copy.

Key words: National Digital Archives, Poland, online access, use

Il servizio internet Cerca in Archivio: nuove possibilità di utilizzo del materiale archivistico

\section{SINTESI}

Il servizio Cerca in archivio è un progetto dell'Archivio nazionale digitale. Obiettivo primario del progetto è quello di rendere disponibile online la descrizione dei materiali archivistici dell'Archivio di Stato e di altre istituzioni culturali. Inoltre, descrizioni selezionate di materiali archivistici sono presentati assieme alle loro scansioni. Il principio del servizio è quello della totale accessibilità ed apertura, l'utilizzo è libero e non richiede iscrizione. Le copie dei materiali archivistici presenti nel servizio, a meno che non vi sia diversa indicazione nelle descrizioni dei materiali o sulle stesse copie digitali, possono essere liberamente utilizzate. A fini informativi, è consigliato di indicare la fonte delle copie digitali.

Parole chiave: Archivio Digitale Nazionale, Polonia, accesso web, utilizzo

Spletna storitev Search in the Archives: nova možnost uporabe arhivskega gradiva

$$
\text { IZVLEČEK }
$$

Storitev Search in the Archives je projekt Nacionalnega digitalnega arhiva. Primarni cilj je omogočiti uporabo popisov arhivskega gradiva iz državnih arhivov in drugih kulturnih ustanov preko spleta. Poleg tega so izbrani opisi arhivskega gradiva predstavljeni hkrati s skeniranim gradivom. Načelo storitve je poln dostop in odprtost, njegova uporaba pa je brezplačna in ne zahteva prijave v sistem. Kopije arhivskega gradiva, ki je na voljo v siste$\mathrm{mu}$, so brezplačne in se lahko prosto uporabljajo, razen če v popisu v sami digitalni kopiji ni navedeno drugače. $\mathrm{Za}$ informativne namene se priporoča, da se navede vir digitalne kopije.

Ključne besede: Nacionalni digitalni arhiv, Poljska, spletni dostop, uporaba

The origins of the site Search in the Archives (www.szukajwarchiwach.pl) date back to November 2009 when, for the first time, 1.2 million descriptions of archival units and 70 thousand scans of archival materials were made available to all those interested. All descriptions and scans came from the State Archives in Lublin. In subsequent years, the number of scans and descriptions available on the site has been increasing, and data from other archives have been gradually added. 
At the end of 2015, nearly 18 million scans of archival materials from the archival resources of 31 state archives were available in the service. It is planned that at the end of 2016 the number of digital copies available on the site will exceed 20 million. Already in April 2016 the service Search in the Archives offered more than 18 million scans of the resources of the state archives. Apart from the birth, marriage and death records from thousands of places in Poland and the records of residents (including Krakow, Poznan and Lodz), the site also makes available, among others, family records, town and city records, the records of the Polish Government in Exile, the Office of the Reconstruction of the Capital, Polish branch of the broadcasting station Radio Free Europe, files concerning German concentration camps from the World War II and the ghetto of Lódź. The service also includes documents concerning the Zamoyski family from the years 1800-1942, from the collection of Zamoyski Museum in Kozłówka, and the records of Polish embassies and missions from the period before World War II, from the resources of the Archives of Hoover Institution ${ }^{1}$.

The service Search in the Archives is the largest in Poland source of historical documentation available on-line: at the end of 2015 it had been visited by more than 1.6 million of unique users. Daily, the documents are used by about 3 thousand people. Since the service is being supplement with further descriptions and scans, also the number and length of sessions are increasing. Most users come from the Poland (73\%), Germany, the United States, France and Great Britain ${ }^{2}$. As shown by the statistics including the areas of research and the interests of archival users, in currently the most common goal of research conducted in the state archives is genealogical research and the number of people, both at home and abroad, who want to know the history of their ancestors, is growing steadily. For this reason, the archives first digitize and make available on the Internet the birth, marriage and death records and they also create indexes to help find a given document. Currently, the service is the largest source of documents for genealogical research. Through it one can access the birth, marriage and death records dating back to 100 years or more ${ }^{3}$ issued by registry offices, parishes and religious communities of various denominations all over the country. In addition, the site successively publishes censuses, population files, residency books as well as mortgages and notarial records.

In April 2015, the service received the Skrzydta IT w Administracji (Wings IT Administration) award in the category $A$ tool for communicating with citizens.

Copies of archival materials presented on the site, unless indicated otherwise in the description of these materials or on the digital copies themselves, can be used freely, including downloading from the site to a local drive, copying and distribution in any other way with the use of any technique. For information purposes, it is recommended to provide the source a digital copy in the form of an active link to the site of its presentation on the service szukajwarchiwach.pl or, if this is not possible, by giving a source in the form of a signature: „The material comes from the service www.szukajwarchiwach. $\mathrm{pl}$ from the collection [here the name of the given archive, storing the originals, must be specified]".

The source of the descriptions of archival materials placed in the service is the data from the application Integrated Archive Information System (ZoSIA). This is - now used in part, but finally in all state archives - an application designed to keep records and develop archival materials. Currently, the application ZoSIA is used in 27 institutions, including 12 state archives ${ }^{4}$.

Initially, the site Search in the Archives used scans prepared by the state archives in the context of individual digitization plans and programs. Since 2012, the digitization of archival collections has been conducted within the framework of the program ordered by the General Director of State Archives, Digitization of Archival Materials from Polish and Foreign Archival Resources. Used for this purpose are also resources from the program implemented in the years 2011-2015, Multi-annual Programme for Government CULTURE+ Priority Digitization by the Ministry of Culture and National Heritage, scans are also made in cooperation with museums, libraries and community organizations.

1. http://archiwalna.archiwa.gov.pl/pl/component/content/article/4394.html?template=archiwa_home (accessed on 19.04.2016); http://www.archiwa.gov.pl/digitalizacja/digitalizacja-i-udost\%C4\%99pnianie-w-interneciedokument\%C3\%B3w-z-zasobu-archiw\%C3\%B3w-pa\%C5\%84stwowych (accessed on 19.04.2016).

2. http://archiwalna.archiwa.gov.pl/pl/component/content/article/4394.html?template=archiwa_home (accessed on 19.04.2016).

3. In accordance with Polish regulations, state archives take over birth marriage and death records 100 years after the closure of a given book.

4. http://www.nac.gov.pl/archiwum-cyfrowe/systemy-i-infrastruktura-it/zosia/ (accessed on 19.04.2016). 
Between 2012 and 2015 state archives made more than 53 million digital copies of archival documents. Only in 2015 state archives acquired 12.5 million scanned documents. Within the framework of the Programme of digitization of archival materials, with the participation of 26 state archives, 1.8 million scans were made. Within the Multi-annual Programme for Government CULTURE+ Priority Digitization, with the participation of 12 state archives - 2.1 million scans. As part of their own activities and in cooperation with other institutions, such as genealogical societies, state archives enlarged the digital resources by 7.5 million scans. Moreover, within the framework of the EU project Genealogical Sources of the Residents of Kujawsko-Pomorskie Voievodship, nearly 1.1 million scans were made of birth, marriage and death records from the resources of the state archives in the Torun and Bydgoszcz 5 .

The conclusions concerning the functioning of the service Search in the Archives are obvious: both the archives and their users derive benefits from this solution. The former reduce the number of original files available in the reading rooms, so the files are not exposed to possible damage due to frequent use. The latter can conveniently use both the inventory descriptions and copies of files on their own computers.

However, we cannot talk about projects of digitization of archival materials by the Polish state archives in order to make them available on-line in isolation from European regulations. First of all, we should recall the Commission Recommendation of 27 October 2011 on the digitisation and online accessibility of cultural material and digital preservation (2011). In the contents of Recommendations we should pay attention to three issues raised. Firstly, the change of the context in which actions related to digitization are taken, namely the international cooperation within the framework of the Europeana project, launched on the $20^{\text {th }}$ November, 2008. The document points out that digitization is an important means to ensure the widest possible access to cultural heritage, including archival materials, and that the coordinated activities of many countries in this field will ensure optimal selection of materials and will enable us to avoid their duplication. Secondly, the issue of protection and respect of copyright and related rights. Here we read that the Commission recommends the wide use of digital materials but with full respect for the copyright and related rights. Attention is also drawn to the fact that only part of the materials kept in the archives (as well as libraries and museums) belongs to the so-called public domain, that is, the regulations concerning the protection of intellectual property do not refer to it. The Recommendations also refer to earlier proposals made by the Commission and concerning the works called orphan works, which led to the conclusion that European Union should create a field for uniform rules in that regard which would be applicable in the whole Union. Thirdly the matters of proper management, maintenance, security of digital materials which create both technical and financial challenges. Recommendations also formulate guidelines for all EU Member States in the following areas: Digitization: organization and funding; Digitization and the Internet availability of materials belonging to the public domain; Digitization and the Internet availability of materials protected by copyrights; Europeana (the issue of further development); Protection of Digital resources. These guidelines are often limited to comments and suggestions of rather general nature, though they also define quite concrete directions of actions and show the way that should be followed.

And a few words about Polish regulations: the Minister of Culture and National Heritage, on the $24^{\text {th }}$ April 2006 appointed a Team for digitization, which is his auxiliary body. The Team consists of representatives of archives, libraries, museums, audiovisual archives and the Ministry of Culture and National Heritage. The task of the team was to develop a unified strategy for digitization and uniform requirements concerning digitization, sharing and storage of digital content, as well as coordination of the digitization process. In 2007, the Team recommended the establishment of a National Centre of Competence for Digitization, monitoring the digitization of archives, libraries and museums as well as audiovisual materials. In 2008, the Team prepared a document Development of technical standards for digital objects created during the digitization of cultural heritage, which provides basic recommendations concerning technical standards to be met by digital materials produced in Polish cultural institutions. Adherence to those recommendations will promote the security of digital materials and will guarantee full conversion of data into new formats in the future.

5. http://www.archiwa.gov.pl/digitalizacja/digitalizacja-i-udost\%C4\%99pnianie-w-internecie-dokument\%C3\%B3w-zzasobu-archiw\%C3\%B3w-pa\%C5\%84stwowych (accessed on 19.04.2016). 
In 2009, the minister established centers of competence for the digitization of archival materials, the digitization of library materials, the digitization of monuments and museum exhibits and for the digitization of audiovisual materials. In the same year a team was established for the planning and coordination of digitization process and sharing of cultural heritage resources and scientific achievements through the IT network.

Sub teams responsible for financial, organizational, technical and legislative matters were established as well.

In 2009, commissioned by the Ministry of Culture and National Heritage, a document was prepared Programme of digitization of cultural heritage and the collection, storage and sharing of digital objects in Poland from 2009 to 2020, which was divided into three key tasks: 1. Development of Polish digital resources; 2. Protection of digital resources; 3. Providing access to digital resources.

It is not only European but also Polish documents that emphasize the great importance and necessity of conducting work in the field of digitization and online sharing of archival materials. Attention is also paid to the ongoing need to introduce common solutions in the field of technical and financial matters connected with the digitization of archival materials. They also point to not fully resolved issues related to copyright protection and management of digital content and securing it. In this context, the question of legal protection of databases is not without significance.

In the Digitization Programme we read, among other things: The overall objective of digitization of archival, library and museum materials as well as storage of natural digital documents is to ensure that all of society, by building appropriate digital resources, will have the widest possible access to cultural heritage and scientific legacy. (...) Digitization, as a new way of processing cultural and scientific content, will make sense only if its effects are available quickly and openly to the greatest number of citizens interested in the presented content. So far, digitization was performed in cultural institutions in Poland (...) without explicit legal rules regulating the access to the collections. It gave rise to the obvious risk of duplication of work, irrational spending of funds and failure to comply with uniform standards, and even the illegal exploitation of copyright in new fields of use or processing of personal data ${ }^{6}$.

As to the Law on the Protection of Personal Data (recently amended in 2015) states in Article 28 paragraph. 1, that: (...) archives can (...) reproduce works contained in their own collections in order to supplement, preserve or protect these collections, share collections for research or cognitive purposes via system terminals located in these units if these activities are not made to achieve direct or indirect financial gain.

In the article $35^{8}$ paragraph. 1, we reads: An authorized person, who (...) is entitled to property copyright to music work considered orphaned, may require that the subject who entered the track to the database, (...) revocates orphan status to the extent to which he will show his rights to the song. And further: Admissibility of the use of orphan works (...) shall expire upon revocation of orphan status in terms of the rights of the holder and publication of information about it in the database (...) (art. $35^{8}$, paragraph. 2). And: If the request of the entitled (...) who showed his rights to orphan works is not considered within one month from the date of delivery, the permissibility of the use of orphan works by the subject to which the request was sent, shall terminate on expiry of that period (art. $35^{8}$, paragraph. 3). The entitled (...) may demand (...) payment of fair compensation for the use of his work as an orphan work. The compensation takes into account the nature and extent of the use of this work, the amount of revenue received on the basis of art. $35^{5}$ paragraph. 3, second sentence [These subjects can obtain revenues from such use, provided that they are intended to cover the direct costs of digitization and public access to orphan works.] and the damage that has been caused to the entitled in connection with the use (art. $35^{8}$, paragraph. 5).

Art. $35^{10}$ paragraph. 2: Archives, educational institutions, universities, research units (...) and cultural institutions may, under an agreement with an organization of collective management of copyright designated by the minister responsible for culture and national heritage protection, reproduce works contained in their collections and not available commercially, published for the first time on Polish territory before the $24^{\text {th }}$ May 1994 and make them available to the public in such a way that everyone can have access to them in a place and time individually chosen by them. 
We cannot omit the question of the proper protection and storage of electronic documents, which today is a great challenge. The challenge which is both the instability of the media, rapidly changing technologies and operating systems, as well as the lack of specific rules for storing, sharing, and security (in the wider sense of the word, also as ensuring the integrity of data) of electronic documents. Especially big is a challenge for cultural and scientific institutions, including archives, also due to financial and organizational considerations.

\section{Used bibliography}

Commission Recommendation of 27 October 2011 on the digitisation and online accessibility of cultural material and digital preservation (2011). Official Journal of the European Union 29.10.2011 (en) L 283/39.

Directive 2012/28/EU of the European Parliament and of the Council of 25 October 2012 on certain permitted uses of orphan works (2012). Official Journal of the European Union 27.10.2012 (en) L 299/5.

Standards in the process of digitization of cultural heritage objects. Ed. G. Płoszajski. Warszawa, 2008.

The Act of the $11^{\text {th }}$ September 2015 amending the Act on Copyright and Related Rights Act and Gambling Act (Dz. U. 2015, item. 1639).

The program of digitization of cultural goods and the collection, storage and sharing of digital objects in Poland 2009-2020 (2009). Available at: http://www.kongreskultury.pl/library/File/RaportDigitalizacja/Program\%20 digitalizacji\%202009-2020.pdf (accessed on 20.04.2016).

Ustawa z dnia 11 września 2015 r. o zmianie ustawy o prawie autorskim i prawach pokrewnych oraz ustawy o grach hazardowych (DZ.U. 2001 poz. 1402).

Ustawa z dnia 27 lipca 2001 r. o ochronie baz danych (z późn. zm.) (Dz.U. 2001 poz. 1402).

\section{SUMMARY}

Creating sites which enable the use of copies of archival materials on the Internet is a sign of our times. Besides the obvious benefits for both parties - the institutions that provide their files and people using those files, it also brings some specific challenges and problems. The most important seem to be those related to the management and protection of electronic documents, as well as the protection of copyright to published documents.

Typology: 1.04 Professional Article

Submitting date: 01.02 .2016

Acceptance date: 20.02.2016 
